\title{
In vitro Comparison of Pancreatic Enzyme Preparations Available in the Indian Market
}

\author{
Shailesh V Shrikhande' \\ VG Mohan Prasad ${ }^{2}$ \\ J Enrique Domínguez- \\ Muñoz ${ }^{3}$ \\ Kevin E Weigl ${ }^{4}$ \\ Kushal D Sarda ${ }^{5}$ \\ 'Division of Cancer Surgery and \\ Gastrointestinal and Hepato-Pancreato- \\ Biliary Service, Tata Memorial Hospital, \\ Mumbai, Maharashtra, India; \\ ${ }^{2}$ Department of Gastroenterology, Dr. M. \\ G.R. Medical University and VGM \\ Hospital, Coimbatore, Tamil Nadu, India; \\ ${ }^{3}$ Department of Gastroenterology and \\ Hepatology, University Hospital of \\ Santiago de Compostela, Santiago de \\ Compostela, Spain; ${ }^{4}$ Department of \\ Gastroenterology, Abbott Laboratories \\ $\mathrm{GmbH}$, Hannover, Germany; ${ }^{5}$ Established \\ Pharmaceuticals Division - Medical \\ Affairs, Abbott India Ltd, Mumbai, \\ Maharashtra, India
}

Correspondence: Kushal D Sarda Abbott India Ltd, Floor 16, Godrej BKC, Plot No. C - 68, Bandra-Kurla Complex, Near MCA Club, Bandra (E), Mumbai, 40005I, Maharashtra, India

Tel +9l-22-38I60938

Fax +91 2238162400

Email kushal.sarda@abbott.com
Purpose: Pancreatic enzyme replacement therapy (PERT) involves exogenous enzyme supplementation and is used in the treatment of pancreatic exocrine insufficiency. Clinical efficacy of PERT preparations is a function of physical properties and release kinetics that vary between commercially available products. In this study, we evaluated the physical properties, in vitro dissolution, and release kinetics of commercially available pancreatic enzyme preparations available in the Indian market.

Methods: Physical properties such as particle size distribution and water content of the capsules were measured by dynamic light scattering and Karl-Fischer titration method, respectively. An analytical procedure based on the European pharmacopoeia (EP) method was used to determine lipase activity, and a modified United States pharmacopoeia (USP)based method was used for dissolution studies. Enzyme release was ascertained under gastroduodenal conditions in buffered media.

Results: Considerable variations in physical properties such as particle size and water content were observed between pancreatic enzyme preparations. Some preparations failed to meet the labeled lipase content as per USP standards ( $>90 \%$ label claim) and showed inconsistent release behavior ( $>5 \%$ relative standard deviation).

Conclusion: Differences exist between pancreatic enzyme preparations in terms of physical properties, dissolution, and release behavior that can affect their clinical efficacy. The present study suggests, therefore, that these preparations should not be used interchangeably.

Keywords: pancreatic enzyme, physical properties, in vitro dissolution, lipase activity, release kinetics

\section{Introduction}

Pancreatic exocrine insufficiency (PEI) is defined as inadequate intraluminal pancreatic enzyme activity, due to insufficient enzyme production, insufficient enzyme activation, or early enzyme degradation leading to maldigestion and malabsorption of nutrients. PEI can be classified as primary or secondary. Primary PEI is due to lack of exocrine pancreatic tissue or disturbances in the postprandial stimulation of pancreatic secretion, whereas inappropriate enzyme activation or inadequate mixing of enzymes with the chyme after surgery causes secondary PEI. ${ }^{1}$ PEI is a condition that is commonly associated with several pancreatic diseases such as chronic pancreatitis, acute necrotizing pancreatitis, ductal obstruction of the pancreas of any etiology, cystic fibrosis, pancreatic and periampullary cancer, or surgical procedures such as pancreatectomy, gastrectomy, or gastrointestinal bypass surgery. ${ }^{2}$ Insufficient secretion of pancreatic enzymes (lipases, proteases, and amylases) into the duodenum results in nutrient malabsorption, which may cause weight 
loss, gastrointestinal symptoms such as diarrhea, abdominal distension, abdominal cramps, flatulence and bloating, and nutritional deficiencies of proteins, essential amino acids, fatty acids, micronutrients, and fat-soluble vitamins. $^{2-4}$

Pancreatic enzyme replacement therapy (PERT) is the cornerstone of PEI management and involves oral replacement of pancreatic enzymes. Exogenous enzyme supplementation minimizes the malabsorption of fat, carbohydrate, and protein from the diet and improves symptoms of PEI. ${ }^{5,6}$ Pancreatic enzyme preparations differ in the content of their lipase, amylase, and protease enzymes and are conventionally labeled depending upon their lipase activity. ${ }^{7}$

An effective PERT preparation should intersperse well with chyme, resist inactivation by gastric juices, empty from the stomach simultaneously with nutrients, and release enzymes rapidly in the proximal small intestine. ${ }^{7,8}$ Modern pancreatic enzyme preparations are $\mathrm{pH}$-sensitive, enteric-coated pellets that protect the enzymes from gastric acidity. They provide a large surface area and their small size allows the preparation to pass through the pylorus and facilitates ready dispersal in chyme. $^{7-10}$ Enteric-coated microspheres of $<2 \mathrm{~mm}$ in size are the preparations of choice for PEI. ${ }^{9}$

The United States Food and Drug Administration (US FDA) decided to change the status of pancreatic enzyme products from over-the-counter to prescription-only status due to their non-comparability and further advocated treatment monitoring by a physician. These differences were attributed to the manufacturing process used for enteric coating formulations. ${ }^{2,11}$ In order to justify their interchangeable use, variability in the lipase content and release of enzymes from different formulations make it important to investigate commercially available pancreatin preparations (branded and generic) regarding key performance metrics that can ultimately affect availability of the enzyme and clinical response in vivo. Previous studies have indicated variation in pancreatic enzyme products available in Western Europe and Russia in terms of actual enzyme content and in vitro release; however, no such studies were performed on pancreatic enzyme products marketed in India. $2,7,8$

The objective of this study was to compare the physical properties, formulation characteristics, and in vitro dissolution and release kinetics of various pancreatin preparations available in the Indian market.

\section{Materials and Methods \\ Materials}

In this study, 10 batches of pancreatic enzyme capsule preparations $\left(\right.$ Creon $^{\circledR} 10,000$, Creon $^{\circledR} 25,000$, Creon $^{\circledR} 40,000$, Agna $^{\mathrm{TM}}$ 10,000, Agna $^{\mathrm{TM}} 25,000$, Enzar $^{\mathrm{TM}}$ 10,000, Enzar ${ }^{\mathrm{TM}}$ 25,000 or EnzarTM HS, EnzarTM 40,000, Panlipase ${ }^{\circledR} 10,000$, and Panlipase ${ }^{\circledR} 25,000$ ) were analyzed. All preparations were encapsulated enteric-coated pellets, which were either colorcoded or labeled according to their strength. The labeling on the products corresponded to lipase content in European Pharmacopoeia (EP) or United States Pharmacopoeia (USP) units. ${ }^{12,13}$ Table 1 contains an overview of the products that were analyzed in the study.

\section{Particle Size Distribution}

Particle size analysis was performed using a Qicpic dynamic imaging system (Sympatec $\mathrm{GmbH}$ ) with a gravity disperser GRADIS with 4-mm split and the feeding system VIBRI. ${ }^{8}$ Each batch was analyzed in triplicate. The start of each measurement was triggered by reaching an optical concentration of $\geq 0.2 \%$. The sample was automatically dry dispersed and analyzed with the Qicpic. The M7 (10-3410 $\mu \mathrm{m})$ measuring range was used for particle size determination. Feret $\max \mathrm{X}_{50}$ was used to describe the size of the particles. Particle sizes were represented with the aid of the percentile range $\mathrm{X}_{50}$, which represents the particle size at which $50 \%$ of the material is smaller than this range.

\section{Water Content}

Water content was determined using a method based on the Karl-Fischer coulometric titration method. Water was evaporated by heating $\left(130^{\circ} \mathrm{C}\right)$ the sample in a Metrohm KF-Oven Sample Processor 774 and transferred by a nitrogen stream $(80 \mathrm{~mL} / \mathrm{min})$ into the Metrohm Coulometer 831 with 774 SC Controller measuring cell. Water in the measuring cells reacts with iodine and sulfur dioxide (contained in the Karl-Fischer reagent) by releasing iodine ions and protons. The amount of water thus correlates to the protons, which are quantitated by titration using the Metrohm Dosino 800 Dosing System and Metrohm 846 Dosing Interface. The absolute water amount of a sample is calculated by the measured value of total water in the sample minus the water determined for the blank. The water content of a sample in $\%(w / w)$ is calculated relative to the sample weighting by the system. The contents of 20 capsules were combined and then samples of 100-200 mg were analyzed $(\mathrm{n}=2$ per product). 
Table I Overview of Pancreatic Enzyme Products Investigated

\begin{tabular}{|c|c|c|c|c|c|}
\hline Brand Name (Manufacturer) & $\begin{array}{l}\text { Label Claim }^{\mathrm{a}}(\mathrm{L}, \\
\qquad \text { A, P) }\end{array}$ & Batch & $\begin{array}{l}\text { Manufacturing } \\
\text { Date }\end{array}$ & $\begin{array}{l}\text { Expiry } \\
\text { Date }\end{array}$ & $\begin{array}{l}\text { Capsule } \\
\text { Content }\end{array}$ \\
\hline Creon $^{\circledR}$ 10,000 (Abbott Laboratories, Germany) & $\begin{array}{c}10,000 \\
8000 \\
600\end{array}$ & CNA9046 & Sep 2019 & Aug 2021 & $\begin{array}{c}150 \mathrm{mg} \\
\text { Pancreatin IP }\end{array}$ \\
\hline Creon $^{\circledR} 25,000$ (Abbott Laboratories, Germany) & $\begin{array}{c}25,000 \\
18,000 \\
1000\end{array}$ & CNB90I3 & Oct 2019 & Sep 2021 & $\begin{array}{c}300 \mathrm{mg} \\
\text { Pancreatin IP }\end{array}$ \\
\hline Creon $^{\circledR} 40,000$ (Abbott Laboratories, Germany) & $\begin{array}{c}40,000 \\
25,000 \\
1600\end{array}$ & CNC90II & Aug 2019 & Jul 202I & $\begin{array}{c}400 \mathrm{mg} \\
\text { Pancreatin IP }\end{array}$ \\
\hline Agna $^{\text {TM }}$ I0,000 (Hetero Labs Limited, India) & $\begin{array}{c}10,000 \\
8000 \\
600\end{array}$ & GNAI 90905 & Sep 2019 & Aug 202I & $\begin{array}{l}170 \mathrm{mg} \\
\text { Pancreatin IP }\end{array}$ \\
\hline Agna $^{\text {TM }}$ 25,000 (Hetero Labs Limited, India) & $\begin{array}{c}25,000 \\
18,700 \\
1000\end{array}$ & GNBI90302 & Mar 2019 & Feb 2021 & $\begin{array}{c}350 \mathrm{mg} \\
\text { Pancreatin IP }\end{array}$ \\
\hline Enzar TM 10,000 (Torrent Pharmaceuticals, India) & $\begin{array}{c}10,000 \\
6000 \\
350\end{array}$ & TOREA9002 & Jul 2019 & Jun 2021 & Unknown \\
\hline $\begin{array}{l}\text { Enzar }{ }^{\mathrm{TM}} 25,000 \text { (Enzar HS) (Torrent } \\
\text { Pharmaceuticals, India) }\end{array}$ & $\begin{array}{c}25,000 \\
18,000 \\
1000\end{array}$ & WBC39013 & Aug 2019 & Jul 202I & $\begin{array}{c}250 \mathrm{mg}^{\mathrm{b}} \\
\text { Pancreatin IP }\end{array}$ \\
\hline Enzar TM 40,000 (Torrent Pharmaceuticals, India) & $\begin{array}{c}40,000 \\
24,000 \\
1600\end{array}$ & TOREB900I & May 2019 & Apr 2021 & Unknown \\
\hline $\begin{array}{l}\text { Panlipase }{ }^{\circledR} \text { I0,000 (Sun Pharmaceutical Industries, } \\
\text { India) }\end{array}$ & $\begin{array}{l}10,000 \\
33,200 \\
37,500\end{array}$ & BSUI3I0 & Sep 2019 & Feb 202I & $\begin{array}{c}150 \mathrm{mg} \\
\text { Pancreatin IP }\end{array}$ \\
\hline $\begin{array}{l}\text { Panlipase }{ }^{\circledR} 25,000 \text { (Sun Pharmaceutical Industries, } \\
\text { India) }\end{array}$ & $\begin{array}{l}25,000 \\
74,700 \\
62,500\end{array}$ & ESUI875 & Nov 2019 & Apr 2021 & $\begin{array}{c}300 \mathrm{mg} \\
\text { Pancreatin IP }\end{array}$ \\
\hline
\end{tabular}

Notes: ${ }^{\mathrm{a} A l l}$ values are in EP units except for Panlipas $\mathrm{e}^{\circledR} 10,000$ and Panlipase ${ }^{\circledR} 25,000$ which are in USP units; ${ }^{\mathrm{b}} \mathrm{According}$ to website http://www. Img.com. Abbreviations: A, amylase enzyme; IP, Indian pharmacopeia; L, lipase enzyme; P, protease enzyme.

\section{Lipase Activity}

Lipase enzymatic assay was performed using a Metrohm 907 Titrando and an analytical procedure based on the EP method. ${ }^{12}$ The amount of olive oil hydrolysis was compared to a reference standard with known activity (pancreas powder BRP) to determine the lipase activity of the sample. ${ }^{12}$ Since the lipase activity of Panlipase ${ }^{\circledR}$ products are listed in USP units, a USP method was additionally used to determine their lipase activity and check the validity of the label claim. The contents of 20 capsules of each product were separated from their capsule shells and combined and milled for the assay $(n=2$ determinations per product). The \% label claim for lipase activity was calculated as follows:

$$
\% \text { label claim }=\frac{\text { Activity found }(\text { activity per cps })}{\text { Label claim }(\text { activity per cps })} \times 100
$$

\section{Enteric Coating Dissolution}

A modified USP dissolution method as described for pancrelipase delayed-release capsules was performed using a Sotax ATR smart dissolution tester. ${ }^{13}$ Sample preparation 
involved removal and mixing of the pellets from 10 capsules of each product. Enough sample to be in the lipase activity measurement range per vessel was tested $(n=6$ determinations per product). Briefly, the pellets were incubated in $800 \mathrm{~mL}$ simulated gastric fluid $(\mathrm{pH} 1)$ for $2 \mathrm{~h}$ in a rotating basket (100 rpm) apparatus (EP/USP basket apparatus). In the second part, the pellets were transferred to $800 \mathrm{~mL}$ of phosphate buffer (pH 6) and stirred for $30 \mathrm{~min}$ in an EP/USP paddle dissolution apparatus at $100 \mathrm{rpm}$. For Agna ${ }^{\mathrm{TM}} 10,000$ and Agna $^{\mathrm{TM}}$ 25,000, the pellets were exposed to $800 \mathrm{~mL}$ phosphate buffer ( $\mathrm{pH}$ 6) in a rotating basket $(100 \mathrm{rpm})$ for 30 min in EP/USP basket apparatus. Samples were taken in the second part at time points 10, 20, and $30 \mathrm{~min}$, and the lipase activity determined. Two vessels containing a reference standard in phosphate buffer were treated under the same conditions as the samples. Actual lipase activity was determined using the procedure described for lipase activity. One sampling and titration were performed per sampling point. Reportable values were mean values per run $(n=6)$ and at different time points.

\section{Enzyme Release}

Enzyme release was analyzed by agitating the pellets in an Erweka Zt 304 disintegration apparatus that mimicked the conditions at the gastroduodenal transit. ${ }^{2}$ The contents of the capsules were separated from their shells and placed in a beaker containing $600 \mathrm{~mL}$ phosphate buffer $\mathrm{pH} 5$ at $37^{\circ} \mathrm{C}$. The pellets were agitated for $60 \mathrm{~min}$ using a basket rack with a mesh bottom after which the $\mathrm{pH}$ was adjusted to 6 and the incubation was continued for another $60 \mathrm{~min}$. The $\mathrm{pH}$ value was kept constant $( \pm 0.1 \mathrm{pH}$ units) in each part with the addition of sodium hydroxide or hydrochloric acid, $4 \mathrm{~mL}$ samples were withdrawn every 15 min, and lipase activity of the sample was determined. The results at each time point were reported as a percentage of the actual lipase activity.

\section{Results}

\section{Particle Size Distribution}

Figure 1 summarizes the particle size information for the tested products $(\mathrm{n}=3)$. The continuous line at $2000 \mu \mathrm{m}$ represents the largest particle size recommended in clinical guidelines for the treatment of PEI. ${ }^{9}$ Creon $^{\circledR}$ and Panlipase $^{\circledR}$ products had $50 \%$ of their pellets smaller than $1.6 \mathrm{~mm}$, whereas Agna $^{\mathrm{TM}}$ and Enzar ${ }^{\mathrm{TM}}$ products had $50 \%$ of their pellets $<1.9 \mathrm{~mm}$. Furthermore, Creon ${ }^{\circledR}$ and Agna $^{\mathrm{TM}}$ products had a wider size distribution with pellets as small as $1-1.1 \mathrm{~mm}$ (data not shown).

\section{Water Content}

The water content of all Creon ${ }^{\circledR}$ products and Enzar ${ }^{\mathrm{TM}}$ 40,000 was below 5\%, while Agna ${ }^{\mathrm{TM}}$ products, Panlipase $^{\circledR}$ products, Enzar ${ }^{\mathrm{TM}} 10,000$, and Enzar ${ }^{\mathrm{TM}} \mathrm{HS}$ had a water content above $5 \%$ (Table 2).

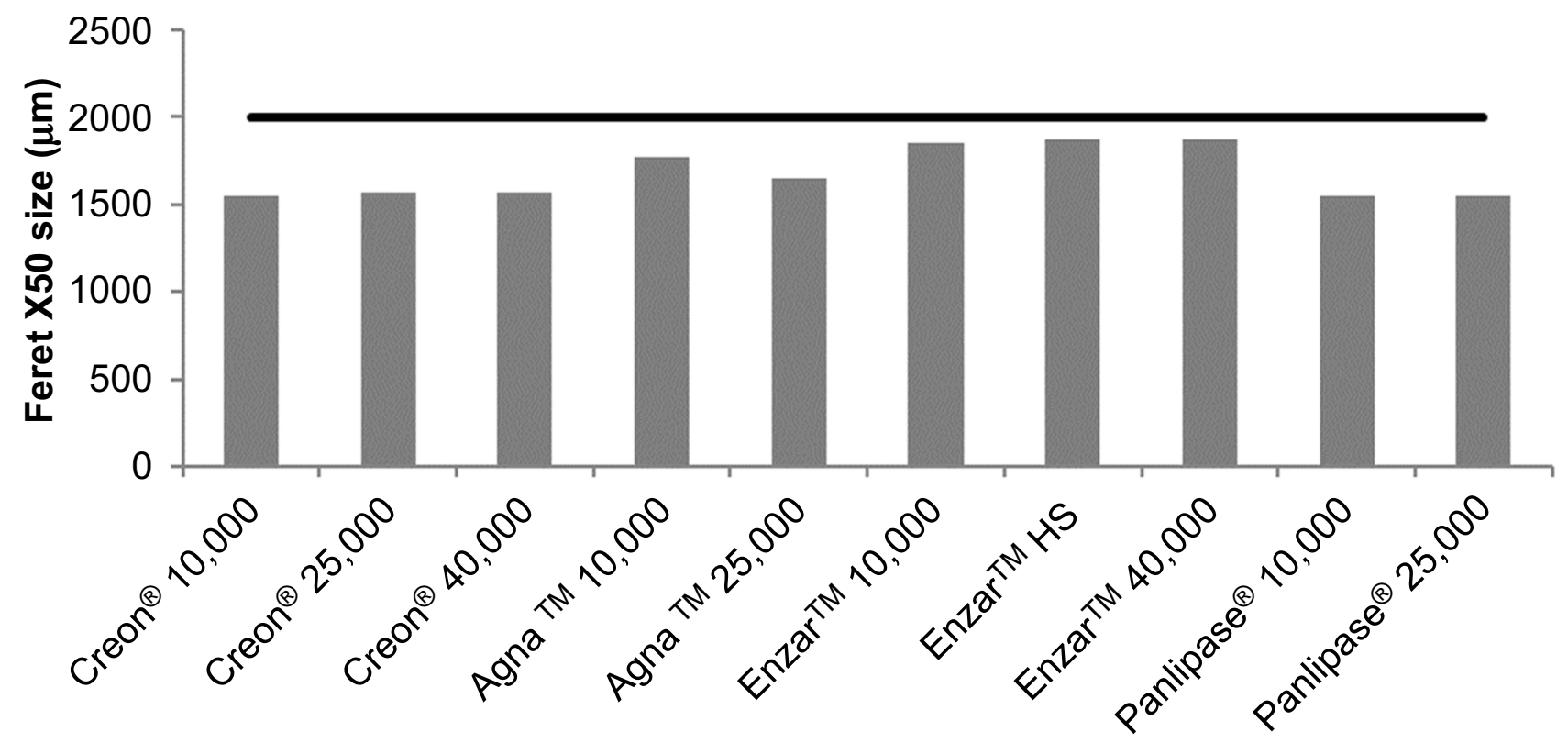

Figure I Particle size of pancreatic enzyme preparations. Feret maximum diameter $\left(\mathrm{X}_{50}\right)$ for Creon $^{\circledR}$, Agna ${ }^{\mathrm{TM}}$, Enzar ${ }^{\mathrm{TM}}$ and Panlipase ${ }^{\circledR}$ pancreatic enzyme products. The continuous line at $2000 \mu \mathrm{m}$ represents the largest particle size recommended in clinical guidelines for the treatment of PEI. 
Table 2 Water Content of Pancreatic Enzyme Products

\begin{tabular}{|l|c|}
\hline Product & Water Content (\%) \\
\hline Creon $^{\circledR} 10,000$ & 4.3 \\
Creon $^{\circledR} 25,000$ & 4.1 \\
Creon $^{\circledR} 40,000$ & 4.1 \\
Agna $^{\text {TM }} 10,000$ & 5.7 \\
Agna $^{\text {TM }} 25,000$ & 5.8 \\
Enzar $^{\text {TM }} 10,000$ & 5.2 \\
Enzar $^{\text {TM }}$ HS & 5.2 \\
Enzar $^{\text {TM }} 40,000$ & 4.5 \\
Panlipase $^{\circledR} 10,000$ & 8.0 \\
Panlipase $^{\circledR} 25,000$ & 8.3 \\
\hline
\end{tabular}

\section{Lipase Activity}

The lipase activities for $\mathrm{Creon}^{\circledR}$, Agna ${ }^{\mathrm{TM}}$, and Enzar ${ }^{\mathrm{TM}}$ products are listed in EP units while those for Panlipase ${ }^{\circledR}$ products are listed in USP units. Agna ${ }^{\mathrm{TM}}$ and Panlipase ${ }^{\circledR}$ products were found to have lipase activity significantly lower than their label claim (Table 3). The EP does not list a monograph on pancreas powder-finished products, but the USP contains a monograph on pancrelipase delayedrelease capsules that provides a minimum lipase activity of 90\%. ${ }^{13}$ Creon $^{\circledR}$ and EnzarTM products met their label claim. In absolute terms, for drug products with a label claim of 10,000 lipase units, the rank order for lipase activity was Creon ${ }^{\circledR} 10,000>$ Panlipase $^{\circledR} 10,000>$ Enzar $^{\mathrm{TM}}$ $10,000>$ Agna $^{\mathrm{TM}} 10,000$. The rank order for lipase activity for drug products with label claim of 25,000 lipase units was $\quad$ Creon $^{\circledR} \quad 25,000>$ Enzar $^{\mathrm{TM}} \quad$ HS $>$ Agna $^{\mathrm{TM}}$

Table 3 Comparison of Actual Lipase Activity to Label Claim in Various Pancreatic Enzyme Products

\begin{tabular}{|c|c|c|c|}
\hline Product & $\begin{array}{c}\text { Label Claim } \\
\text { (Activity per } \\
\text { Capsule) }\end{array}$ & $\begin{array}{l}\text { Activity Found } \\
\text { (Activity per } \\
\text { Capsule) }\end{array}$ & $\begin{array}{c}\% \\
\text { Label } \\
\text { Claim }\end{array}$ \\
\hline Creon ${ }^{\circledR} 10,000$ & 10,000 EP units & $|2,03|$ EP units & 120 \\
\hline Creon $^{\circledR} 25,000$ & 25,000 EP units & $27,66 \mathrm{I}$ EP units & 111 \\
\hline Creon $^{\circledR} 40,000$ & 40,000 EP units & 4I,654 EP units & 104 \\
\hline Agna $^{\mathrm{TM}} \quad 10,000$ & 10,000 EP units & 6,748 EP units & 67 \\
\hline Agna $^{\text {TM }} 25,000$ & 25,000 EP units & $19,217 \mathrm{EP}$ units & 77 \\
\hline Enzar $^{\text {TM }} \quad 10,000$ & $10,000 \mathrm{EP}$ units & 8178 EP units & 82 \\
\hline Enzar $^{\mathrm{TM}} \mathrm{HS}$ & 25,000 EP units & $23,320 \mathrm{EP}$ units & 93 \\
\hline Enzar $^{\mathrm{TM}} 40,000$ & 40,000 EP units & 43,221 EP units & 108 \\
\hline Panlipase ${ }^{\circledR} 10,000$ & $\begin{array}{c}10,000 \text { USP } \\
\text { units }\end{array}$ & 7943 USP units & 79 \\
\hline Panlipase ${ }^{\circledR} 25,000$ & $\begin{array}{c}25,000 \text { USP } \\
\text { units }\end{array}$ & 13,760 USP units & 55 \\
\hline
\end{tabular}

Abbreviations: EP, European pharmacopoeia; USP, United States pharmacopoeia.
$25,000>$ Panlipase ${ }^{\circledR} 25,000$. Finally, the lipase activities of Creon ${ }^{\circledR} 40,000$ and Enzar ${ }^{\mathrm{TM}} 40,000$ were similar.

\section{Dissolution}

The USP monograph for pancrelipase delayed-release capsules specifies a dissolution tolerance of not less than $75 \%$ of the labeled units of lipase activity per capsule within 30 min in phosphate buffer at $\mathrm{pH} 6 .{ }^{13}$

Figure 2 shows the $\%$ dissolved (actual lipase activity) at $20 \mathrm{~min}$ and $30 \mathrm{~min}$ in phosphate buffer $\mathrm{pH} 6$. After an initial incubation in simulated gastric fluid $(\mathrm{pH} 1)$ for $2 \mathrm{~h}$, more than $90 \%$ of Creon ${ }^{\circledR}$ and Enzar ${ }^{\mathrm{TM}}$ products dissolved within $20 \mathrm{~min}$ in phosphate buffer at $\mathrm{pH} 6$ (Figure 2). Under similar conditions, Agna ${ }^{\mathrm{TM}}$ products were slower to dissolve, but reached $>80 \%$ dissolution after $30 \mathrm{~min}$. Agna $^{\mathrm{TM}}$ pellets were observed to be very buoyant, and thus the pellets were placed in a basket apparatus during incubation in phosphate buffer $\mathrm{pH}$ 6. Dissolution of both Panlipase $^{\circledR}$ products was poor, with $<25 \%$ of the pellets dissolving within $30 \mathrm{~min}$ (Figure 2).

\section{Enzyme Release at $\mathrm{pH} 5 / \mathrm{pH} 6$}

To determine the stability of the gastro-resistant coating at $\mathrm{pH}$ 5, enzyme release from the drug products was determined using a disintegration apparatus. Ideally, the products should not release enzymes from $\mathrm{pH} 1$ to $\mathrm{pH} 5$ to avoid the deactivation of the enzymes in the stomach. This should be followed by disintegration of the enteric coating and enzyme release at $\mathrm{pH} 5.5$, mimicking the duodenal conditions. No release of lipase activity was observed for all $\mathrm{Creon}^{\circledR}$ and $\mathrm{Agna}^{\mathrm{TM}}$ products at $\mathrm{pH} 5$ followed by an immediate release at $\mathrm{pH} 6$ (Figure 3A-C). In contrast, significant enzyme release was already observed for Enzar ${ }^{\mathrm{TM}}$ and Panlipase ${ }^{\circledR}$ products at $\mathrm{pH}$ 5. Therefore, the release of lipase activity for Enzar ${ }^{\mathrm{TM}}$ and Panlipase ${ }^{\circledR}$ products was also assessed in phosphate buffer $\mathrm{pH}$ 4. No release was demonstrated for all Enzar ${ }^{\mathrm{TM}}$ products; however, a significant and immediate release of lipase activity was observed for Panlipase ${ }^{\circledR} 10,000$ and a slower, less pronounced release of lipase activity was observed for Panlipase ${ }^{\circledR} 25,000$ (data not shown).

\section{Discussion}

This study provides an in vitro comparison of several pancreatic enzyme preparations available as capsules in the Indian market. In accordance with previous studies, the enzyme preparations differed significantly in terms of their physical properties and in vitro dissolution and release kinetics. ${ }^{2,7,8}$ 


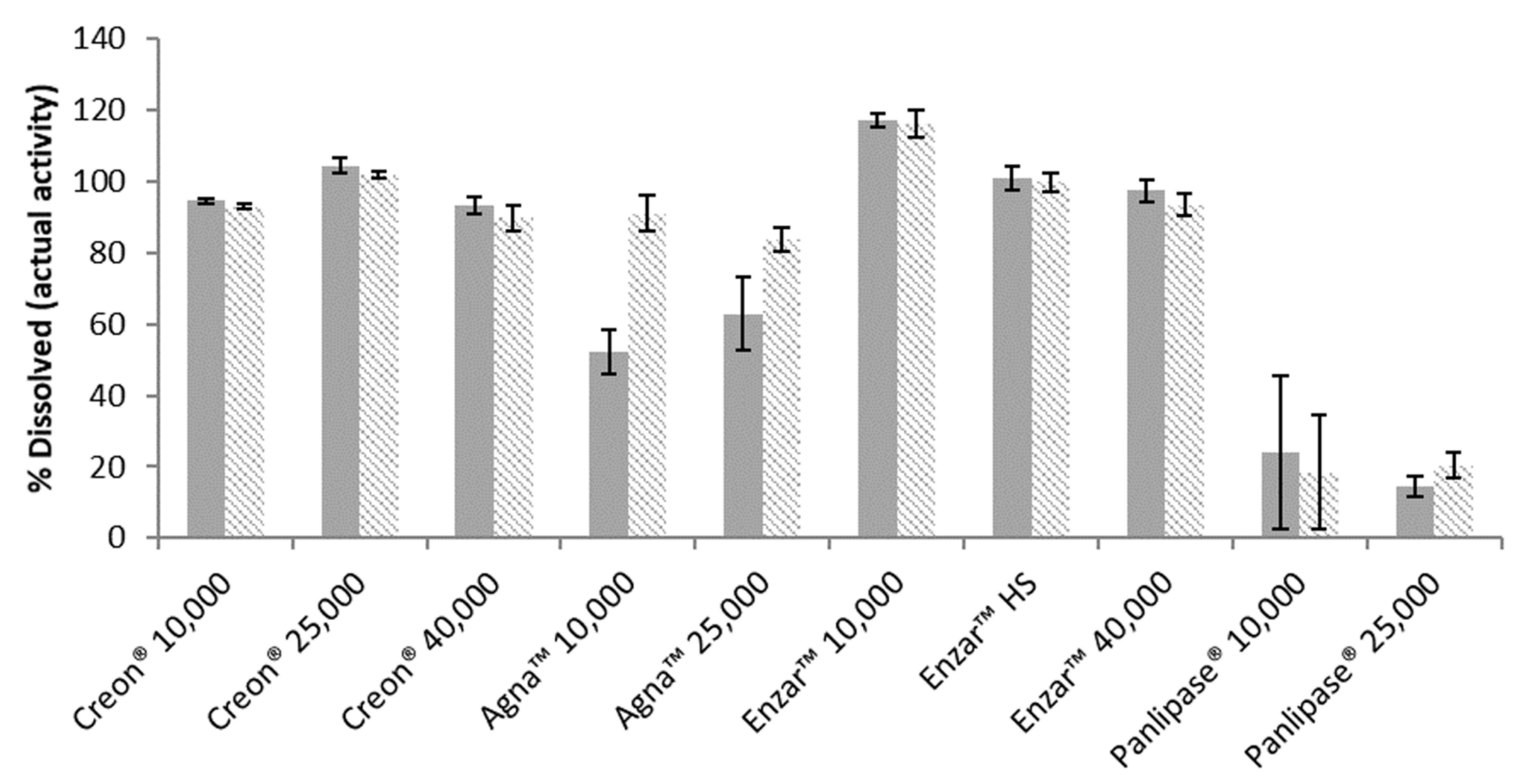

Figure 2 Dissolution of pancreatic enzyme preparations. Dissolution of the different products at 20 min (solid bars) and 30 mins (patterned bars). Test items (pellets from capsules) were first incubated in simulated gastric fluid $(\mathrm{pH} \mathrm{I})$ for $2 \mathrm{~h}$ and then transferred to phosphate buffer $\mathrm{pH} 6$ and stirred for 30 min. Individual points indicate mean (standard deviation) at each time point ( $n=6$ for Creon ${ }^{\circledR}$, Agna ${ }^{\mathrm{TM}}$, Enzar ${ }^{\mathrm{TM}}$ products and Panlipase $^{\circledR} 25,000$ and $\mathrm{n}=4$ for Panlipase ${ }^{\circledR} 10,000$ ).
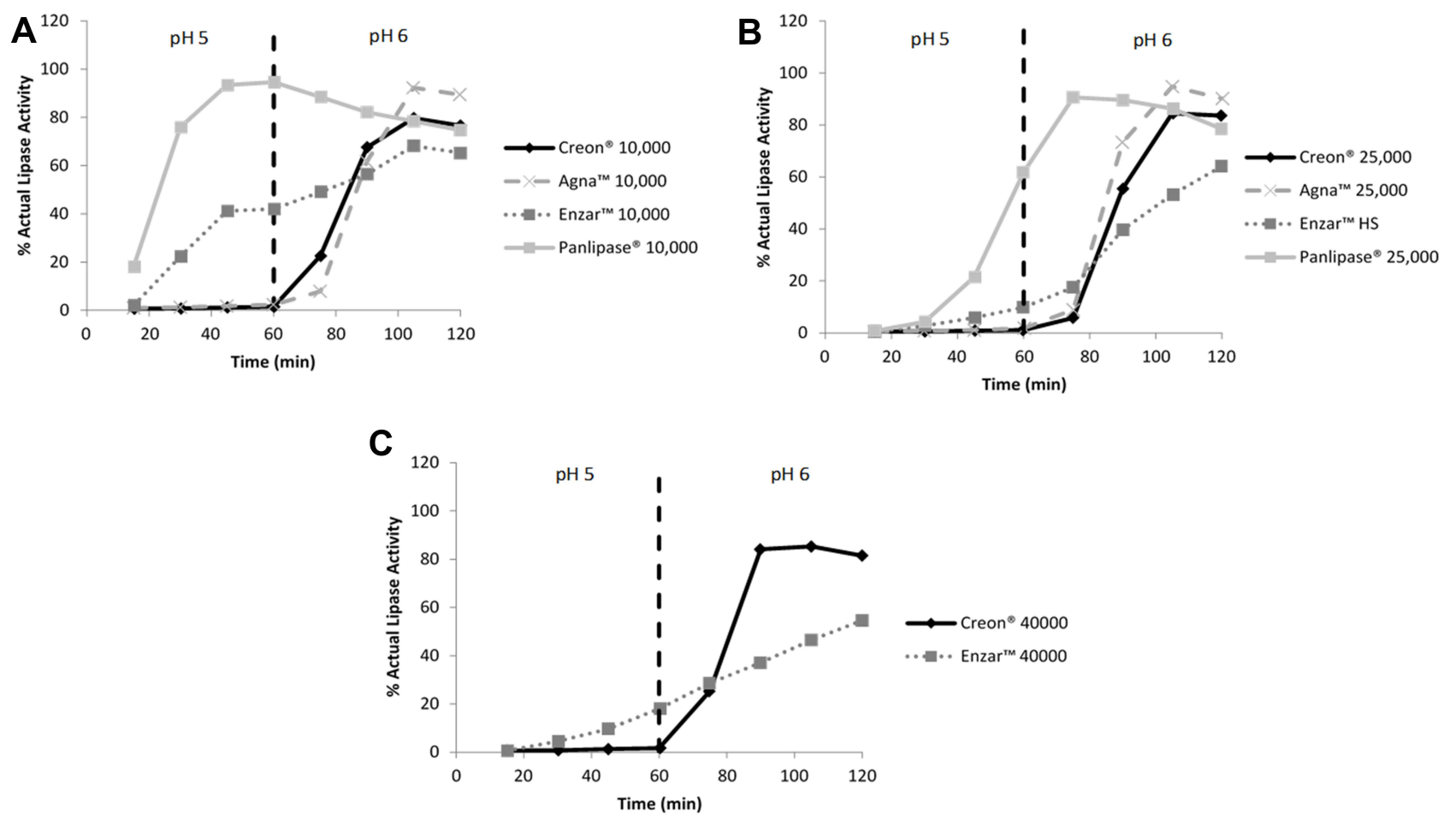

Figure 3 Enzyme release kinetics of pancreatic enzyme preparations. Enzyme release kinetics for (A) Creon ${ }^{\circledR} 10,000$, Agna ${ }^{\mathrm{TM}}$ 10,000, Enzar ${ }^{\mathrm{TM}}$ I0,000, and Panlipase ${ }^{\circledR}$ 10,000 (B) Creon ${ }^{\circledR} 25,000$, Agna ${ }^{\mathrm{TM}}$ 25,000, Enzar ${ }^{\mathrm{TM}} \mathrm{HS}$ and Panlipase ${ }^{\circledR} 25,000$ (C) Creon ${ }^{\circledR} 40,000$ and Enzar ${ }^{\mathrm{TM}} 40,000$. Test items were incubated in phosphate buffer pH 5 for $60 \mathrm{~min}$ and then phosphate buffer $\mathrm{pH} 6$ for $60 \mathrm{~min}$. The vertical dashed line represents the transition between the $\mathrm{pH} 5$ and $\mathrm{pH} 6$. 
Particle size and size distribution of the pellets of pancreatic enzyme preparations have been shown to have implications for their clinical efficacy. ${ }^{14,15}$ Several studies have shown that particles less than $2 \mathrm{~mm}$ in size allow for better dispersal with chyme and simultaneous emptying with chyme from the stomach to the duodenum. ${ }^{6,7,16-19}$ Products with a smaller particle size have been associated with higher lipolytic activity and a more rapid onset of action. ${ }^{14,15}$ In this study, the mean pellet size of Creon ${ }^{\circledR}$, Agna $^{\mathrm{TM}}$, Enzar ${ }^{\mathrm{TM}}$, and Panlipase ${ }^{\circledR}$ products was less than $2 \mathrm{~mm}$. However, when considering the size distribution, $\mathrm{Creon}^{\circledR}$ and Agna ${ }^{\mathrm{TM}}$ products had pellet sizes with a lower limit of $1 \mathrm{~mm}$. Agna ${ }^{\mathrm{TM}}$ pellets were found to be quite buoyant, a characteristic that could potentially affect their passage through the pyloric sphincter and delay their release into the duodenum and subsequent mixing with chyme. Kühnelt et al showed an earlier onset of intraduodenal lipolytic activity for smaller microspheres compared to larger microspheres containing pancreatic enzymes, indicating a relationship between particle size and product efficacy. ${ }^{5}$ Enteric-coated microspheres or mini-microspheres of $<2 \mathrm{~mm}$ size are the preparations of choice for PEI. ${ }^{9}$

The label claim for lipase activity was met by all Creon ${ }^{\circledR}$ products, Enzar ${ }^{\mathrm{TM}}$ HS, and Enzar ${ }^{\mathrm{TM}} 40,000$ according to USP criteria ( $>90 \%$ of label claim). ${ }^{13}$ The lower lipase activity observed for Enzar ${ }^{\mathrm{TM}} 10,000$, Agna $^{\mathrm{TM}}$, and Panlipase ${ }^{\circledR}$ products may be associated with their high water content. Previous experience has shown that water content above 5\% has a negative effect on the stability of lipase, and in our study, products with lipase activity below label claim had water content above $5 \%$. The increased presence of water can catalyze enzymatic degradation and inactivation during product storage, resulting in a decrease in enzymatic activity. Loss of potency during storage can ultimately affect the quantity of enzymes available to support digestion and may result in a suboptimal and variable clinical response.

Ideally, pancreatic enzymatic preparations should exert their effect (ie release of enzyme activity) only once the pellets enter the duodenum together with the chyme. Therefore, they should be stable at low $\mathrm{pH}$ values to prevent deactivation of pancreatic enzymes in the stomach. All the enzymatic products tested in this study contain an enteric coating. It was observed that the digestive enzymes in $\mathrm{Creon}^{\circledR}$, Agna ${ }^{\mathrm{TM}}$, and Enzar ${ }^{\mathrm{TM}}$ products were protected from the simulated gastric fluid at $\mathrm{pH}$ 1 for $2 \mathrm{~h}$, followed by an immediate release at $\mathrm{pH}$ 6. In contrast, the significantly reduced lipase activity of Panlipase ${ }^{\mathbb{R}}$ products is indicative of instability of its enteric coating at $\mathrm{pH} 1$. Although Creon ${ }^{\circledR}$, Agna $^{\mathrm{TM}}$, and Enzar ${ }^{\mathrm{TM}}$ products complied with the dissolution specification, the release from $\mathrm{Creon}^{\circledR}$ and Enzar ${ }^{\mathrm{TM}}$ products was most consistent (relative standard deviation $<4 \%$ ); this may have important implications for the reproducible behavior of these products. Although the $\mathrm{pH}$ of pure gastric secretions is $\mathrm{pH} 1-2$, the buffering capacity and volume of food ingested can cause the $\mathrm{pH}$ in the stomach to rise temporarily to $\mathrm{pH} 5$ and subsequent premature disintegration of coating and release of enzymes can occur. ${ }^{7}$ Any further drop in $\mathrm{pH}$ below 4 due to gastric acid secretion will irreversibly inactivate released pancreatic enzymes. Therefore, it is important to evaluate the release kinetics of the preparations from $\mathrm{pH}$ 5 to $\mathrm{pH}$ 6. The enteric coating of $\mathrm{Creon}^{\circledR}{ }^{\mathbb{B}}$ and $\mathrm{Agna}^{\mathrm{TM}}$ products was stable with no release of lipase activity at $\mathrm{pH} 5$, followed by immediate release at $\mathrm{pH} 6$. In contrast, Enzar ${ }^{\mathrm{TM}}$ and Panlipase ${ }^{\circledR}$ products showed lipase activity at $\mathrm{pH} 5$ indicating a premature release of the enzyme and a loss of activity before reaching the duodenum.

Although this study provides a comparison of the release kinetics from different pancreatin preparations under $\mathrm{pH}$ values that mimic gastroduodenal conditions, it is important to note that studies were carried out in buffered media. Release studies in biorelevant dissolution media or simulated gastric fluids provide a better correlation between in vitro studies and possible clinical performance and should be considered when evaluating the performance of different preparations.

\section{Conclusion}

Considerable differences found between the physical and in vitro release behavior of the pancreatic enzyme preparations available in the Indian market could potentially affect in vivo availability and clinical efficacy. The labeled lipase activity, water content, and dissolution performance specifications were not met for all products. These results confirm findings from previous studies in that various PERT products differ in their in vitro characteristics and adherence to label claim and may therefore not be equivalent in terms of therapeutic effect; thus, treating physicians should be aware of these differences and should exercise caution when recommending replacement or "switching" between products.

\section{Data Sharing Statement}

Authors agree to make their data available upon reasonable request. 


\section{Ethics Approval and Informed Consent}

Not applicable as this is an in vitro study.

\section{Acknowledgments}

The authors thank PharmEDGE for providing medical writing support.

\section{Author Contributions}

All authors made a significant contribution to the work reported, whether that is in the conception, study design, execution, acquisition of data, analysis and interpretation, or in all these areas; took part in drafting, revising or critically reviewing the article; gave final approval of the version to be published; have agreed on the journal to which the article has been submitted; and agree to be accountable for all aspects of the work.

\section{Funding}

The study was funded by Abbott India Ltd.

\section{Disclosure}

J Enrique Domínguez-Muñoz reports personal fees from Abbott Pharmaceuticals, grants from Viatris, outside the submitted work. Kevin E. Weigl is an employee of Abbott Laboratories GmbH, Hannover, Germany. Kushal D. Sarda is an employee of Abbott India Ltd. None of the remaining authors report any conflicts of interest in this work.

\section{References}

1. Lohr JM, Oliver MR, Frulloni L. Synopsis of recent guidelines on pancreatic exocrine insufficiency. United European Gastroenterol J. 2013;1(2):79-83. doi:10.1177/2050640613476500

2. Kuhn RJ, Eyting S, Henniges F, Potthoff A. In vitro comparison of physical parameters, enzyme activity, acid resistance, and $\mathrm{pH}$ dissolution characteristics of enteric-coated pancreatic enzyme preparations: implications for clinical variability and pharmacy substitution. J Pediatr Pharmacol Ther. 2007;12(2):115-128.

3. Fieker A, Philpott J, Armand M. Enzyme replacement therapy for pancreatic insufficiency: present and future. Clin Exp Gastroenterol. 2011;4:55-73.

4. Brennan GT, Saif MW. Pancreatic enzyme replacement therapy: a Concise Review. JOP. 2019;20(5):121-125.

5. NHS UHoL. Pancreatic Enzyme Replacement Therapy (PERT) UHL Guideline B10 2019. Available from: https://secure.library.leicester shospitals.nhs.uk/PAGL/Shared\%20Documents/Pancreatic\% 20Enzyme\%20Replacement \%20Therapy\%20(PERT)\%20UHL\% 20Guideline.pdf. Accessed on 02 Sep 2021.
6. Shandro BM, Nagarajah R, Poullis A. Challenges in the management of pancreatic exocrine insufficiency. World J Gastrointest Pharmacol Ther. 2018;9(5):39-46. doi:10.4292/wjgpt.v9.i5.39

7. Lohr JM, Hummel FM, Pirilis KT, Steinkamp G, Korner A, Henniges F. Properties of different pancreatin preparations used in pancreatic exocrine insufficiency. Eur $J$ Gastroenterol Hepatol. 2009;21(9):1024-1031. doi:10.1097/MEG.0b013e328328f414

8. Maev IV, Kucheryavyy YA, Gubergrits NB, et al. Differences in in vitro properties of pancreatin preparations for pancreatic exocrine insufficiency as marketed in Russia and CIS. Drugs $R$ D. 2020;20 (4):369-376. doi:10.1007/s40268-020-00326-z

9. Lohr JM, Dominguez-Munoz E, Rosendahl J, et al. United European Gastroenterology evidence-based guidelines for the diagnosis and therapy of chronic pancreatitis (HaPanEU). United European Gastroenterol J. 2017;5(2):153-199. doi:10.1177/2050640616 684695

10. Dominguez-Munoz JE. Pancreatic enzyme therapy for pancreatic exocrine insufficiency. Curr Gastroenterol Rep. 2007;9(2):116-122. doi:10.1007/s11894-007-0005-4

11. Federal Register. Docket No. 2003N-0205, Vol. 69, No. 2. Food and Drug Administration; April 28, 2004.

12. European Pharmacopeia, Monograph 0350, Pancreas Powder; 2020. Available from: https://www.edqm.eu/sites/default/files/medias/fich iers/European_Pharmacopoeia/The_European_Pharmacopoeia/ European_Pharmacopoeia_10th_Edition/Index/european_pharmaco peia_supplement_10.2_english_index.pdfhttps://crs.edqm.eu/db/ 4DCGI/leaflet?leaflet $=$ Y0001632_4. Accessed on 02 Sep 2021.

13. USP43-NF38 - page 3384, Current DocID: GUID-B713FD29-65844961-8C46-4A56F436AB85_1_en-US, Pancrelipase DelayedRelease Capsules; 2020. Available from: https://pdf.hres.ca/dpd_pm/ 00057600.PDF. Accessed on 02 Sep 2021

14. Layer P, Groger G, Dicke D. Enzyme pellet size and luminal nutrient digestion in pancreatic insufficiency. Digestion. 1992;52:100-101.

15. Kuhnelt P, Mundlos S, Adler G. [Effect of pellet size of a pancreas enzyme preparation on duodenal lipolytic activity]. Z Gastroenterol. 1991;29(9):417-421. German.

16. Meyer JH, Elashoff J, Porter-Fink V, Dressman J, Amidon GL. Human postprandial gastric emptying of 1-3-millimeter spheres. Gastroenterology. 1988;94(6):1315-1325. doi:10.1016/00165085(88)90669-5

17. Stead RJ, Skypala I, Hodson ME, Batten JC. Enteric coated microspheres of pancreatin in the treatment of cystic fibrosis: comparison with a standard enteric coated preparation. Thorax. 1987;42 (7):533-537. doi:10.1136/thx.42.7.533

18. Norregaard P, Lysgaard Madsen J, Larsen S, Worning H. Gastric emptying of pancreatin granules and dietary lipids in pancreatic insufficiency. Aliment Pharmacol Ther. 1996;10(3):427-432. doi:10.1111/j.0953-0673.1996.00427.x

19. Mundlos S, Kuhnelt P, Adler G. Monitoring enzyme replacement treatment in exocrine pancreatic insufficiency using the cholesteryl octanoate breath test. Gut. 1990;31(11):1324-1328. doi:10.1136/ gut.31.11.1324 


\section{Publish your work in this journal}

Drug Design, Development and Therapy is an international, peerreviewed open-access journal that spans the spectrum of drug design and development through to clinical applications. Clinical outcomes, patient safety, and programs for the development and effective, safe, and sustained use of medicines are a feature of the journal, which has also

been accepted for indexing on PubMed Central. The manuscript management system is completely online and includes a very quick and fair peer-review system, which is all easy to use. Visit http://www. dovepress.com/testimonials.php to read real quotes from published authors.

Submit your manuscript here: https://www.dovepress.com/drug-design-development-and-therapy-journal 